\title{
Genetic Studies on Hypospadias in Males
}

\author{
YOU C. CHEN and PAUL V. WOOLLEY Jr
}

From the Variety Club Growth and Development Center and Cytogenetic Laboratory, Children's Hospital of Michigan, and the Department of Pediatrics, Wayne State University School of Medicine, Detroit, Michigan, USA

Hypospadias is one of the most common urogenital anomalies. It is due to a failure of complete fusion of the urethral folds in the early embryonic stage (Norman, 1963). An excellent review on the possible mode of inheritance was presented by Gates (1946). Other investigators (Sørensen, 1953; Ross, Farmer, and Lindsay, 1959; Rodriquez, 1965) also reported the familial occurrence of this condition. This anomaly appears to be inherited, yet the exact mode of inheritance has not been well delineated.

In hypospadias, karyotypes are normal in most cases. However, many types of chromosomal abnormalities in hypospadias, have been reported in the literature: 47 chromosomes with XXY sex complement (Klotz and Sors, 1958; Halbrecht, 1960; Gray, 1961; Passarge and Thompson, 1964); 47 chromosomes with XYY sex chromosome pattern (Milcu et al, 1964; Chen et al, 1968); a presumably divided $\mathrm{Y}$ chromosome translocated to a chromosome of the 13-15 and of the 21-22 group (de Grouchy et al, 1963); a translocation between a $\mathrm{Y}$ chromosome and a number 21 chromosome (Turpin and Lejeune, 1960); partial deletion of short arms of a number 4 chromosome (Hirschorn, Cooper, and Firschein, 1965; Leao, Neu, and Gardner, 1966); and a deletion of a Y chromosome (Muldal and Ockey, 1962). It appears that these chromosomal abnormalities showed great variations from one hypospadiac to another and no definite aetiological correlations have been established.

This investigation was undertaken to study genetic and non-genetic factors of hypospadias in males, to estimate its heritability assuming the genetic component to be multifactorial, and to analyse the cytogenetic findings.

\section{Materials and Methods}

Eighty-five cases of male hypospadiacs have been observed during 1961 to 1967 at the Children's Hospital of Michigan. Seventy-three cases were admitted for operation, and complete necropsy was done in 6 other

Received 29 July 1970. cases. The remaining 6 cases were diagnosed in the clinic without surgical correction. Their hospital records were systematically reviewed. A questionnaire was designed to obtain the information about date of birth, birth weight, birth rank, parental ages at birth, associated anomalies, presence of consanguinity, and the affected individuals in the relatives. Of 85 patients sent questionnaires, $50(59 \%)$ replied fully. The parents were invited to bring their children to the clinic for careful physical examination. For those patients who could not be examined, the parents were telephoned to ascertain that the information thus obtained was accurate. We were able to conduct cytogenetic studies in 26 cases (Appendix I).

The general population data for birth weight, maternal age at birth, birth order, and seasonal incidence are those of the State of Michigan in 1964.

\section{Results}

The Incidence in the General Population. Steiner (1936) estimated the incidence of hypospadias in the general population to be 1 in 300 to 1 in 1000 male births. The estimate of Sorsby (1953) and that of Fischbein (1963) were very close, being 1 in 330 male births versus 1 in 380 male births. Chung and Myrianthopoules (1968) reported the incidence of 305 cases of hypospadias per 10,000 births for Caucasian boys and 19.5 for the Negro boys. There are 12 Negro boys (24\%) in the present study.

Birth Weights. The observed and expected distributions of birth weights are shown in Table I. There are $19(38 \%)$ premature infants of birth weight less than $2.5 \mathrm{~kg}$; of these, 5 weighed less than $1.5 \mathrm{~kg}$. The birth weight of the smallest one was only $0.9 \mathrm{~kg}$. The mean birth weight for the index cases was $2.7 \mathrm{~kg}$ and $3.3 \mathrm{~kg}$ for the general population. The difference is statistically highly significant $(t=3.39, \mathrm{df}=98, \mathrm{p}<0.001)$.

Parental Age at Birth. The observed and expected distributions of maternal age at birth are shown in Table II. The mean maternal age for the 
TABLE I

COMPARISON BETWEEN

OBSERVED AND EXPECTED

DISTRIBUTION OF BIRTH WEIGHT

\begin{tabular}{l|r|r}
\hline $\begin{array}{c}\text { Birth Weight } \\
(\mathrm{g})\end{array}$ & $\begin{array}{c}\text { Index } \\
\text { Cases }\end{array}$ & $\begin{array}{r}\text { General } \\
\text { Population }\end{array}$ \\
\hline $501-1,000$ & 1 & $0 \cdot 24$ \\
$1,001-1,500$ & 4 & 0.34 \\
$1,501-2,000$ & 8 & $0 \cdot 73$ \\
$2,001-2,500$ & 6 & $2 \cdot 44$ \\
$2,501-3,000$ & 6 & $8 \cdot 79$ \\
$3,001-3,500$ & 18 & $18 \cdot 58$ \\
$3,501-4,000$ & 3 & 13.82 \\
$4,001-4,500$ & 2 & $4 \cdot 14$ \\
$4,501-5,000$ & 1 & 0.80 \\
$5,001-5,500$ & 1 & 0.12 \\
\hline Total & 50 & 50.00 \\
\hline Mean & 2760.00 & 3312.60 \\
\hline SD & 955.60 & 622.20 \\
\hline$t$ & \multicolumn{2}{|c}{3.39} \\
\hline$p$ & $<0.001$ \\
\hline
\end{tabular}

index cases was 24.6 years and 25.9 for the general population. The difference is not significant $(\mathrm{t}=1.005, \mathrm{df}=98,0.3<\mathrm{p}<0.4)$. Mean paternal age at birth was $26 \cdot 80 \pm 5 \cdot 74$. The significance of this figure cannot be determined because of lack of a suitable control population.

TABLE II

COMPARISON BETWEEN OBSERVED AND EXPECTED DISTRIBUTION OF MATERNAL AGE AT BIRTH

\begin{tabular}{l|c|c}
\hline $\begin{array}{c}\text { Maternal } \\
\text { Age }(\mathrm{yr})\end{array}$ & $\begin{array}{c}\text { Index } \\
\text { Cases }\end{array}$ & $\begin{array}{c}\text { General } \\
\text { Population }\end{array}$ \\
\hline $15-19$ & 8 & 6.41 \\
$20-24$ & 19 & 17.91 \\
$25-29$ & 15 & 12.76 \\
$30-34$ & 6 & 7.57 \\
$35-39$ & 1 & 4.14 \\
$40-44$ & 1 & 1.21 \\
\hline Total & 50 & 50.00 \\
\hline Mean & 24.60 & 25.87 \\
\hline SD & 6.41 & 6.23 \\
\hline t & \multicolumn{2}{|c}{1.005} \\
\hline$p$ & \multicolumn{2}{|c}{$0.3<\mathrm{p}<0.4$} \\
\hline
\end{tabular}

Birth Orders. The birth order of index cases can be found in Appendix II. The observed and expected distributions of birth order are shown in Table III. The mean birth order for the index cases was 2.08 and 2.77 for the general population. The difference is significant $(t=2 \cdot 115, d f=98$, $\mathrm{p}<0.005$ ).

Seasonal Incidence. The observed and expected quarterly distributions are shown in Table
IV. There was no significant difference between these two groups $\left(\chi^{2}=2.79, \mathrm{df}=3,0.25<\mathrm{p}<0.50\right)$.

TABLE III

\begin{tabular}{|c|c|c|}
\hline \multicolumn{3}{|c|}{$\begin{array}{c}\text { COMPARISON BETWEEN } \\
\text { THE OBSERVED AND } \\
\text { EXPECTED } \\
\text { DISTRIBUTION OF } \\
\text { BIRTH ORDER }\end{array}$} \\
\hline $\begin{array}{l}\text { Birth } \\
\text { Order }\end{array}$ & $\begin{array}{l}\text { Index } \\
\text { Cases }\end{array}$ & $\begin{array}{c}\text { General } \\
\text { Population }\end{array}$ \\
\hline $\begin{array}{l}1 \\
2 \\
3 \\
4 \\
5 \\
6 \\
7\end{array}$ & $\begin{array}{r}27 \\
9 \\
7 \\
2 \\
2 \\
1 \\
2\end{array}$ & $\begin{array}{r}13.90 \\
11.87 \\
9.58 \\
6.60 \\
4.16 \\
2.43 \\
1.46\end{array}$ \\
\hline Total & 50 & $50 \cdot 00$ \\
\hline Mean & $2 \cdot 08$ & $2 \cdot 77$ \\
\hline SD & $1 \cdot 60$ & 1.65 \\
\hline$t$ & \multicolumn{2}{|c|}{$2 \cdot 115$} \\
\hline $\mathbf{p}$ & \multicolumn{2}{|c|}{$0.02<\mathrm{p}<0.05$} \\
\hline
\end{tabular}

TABLE IV

COMPARISON BETWEEN EXPECTED AND OBSERVED QUARTERLY DISTRIBUTION OF BIRTHS

\begin{tabular}{l|c|c}
\hline Quarter & $\begin{array}{c}\text { Index } \\
\text { Cases }\end{array}$ & $\begin{array}{c}\text { General } \\
\text { Population }\end{array}$ \\
\hline First & 13 & $12 \cdot 16$ \\
Second & 15 & $12 \cdot 43$ \\
Third & 8 & 13.08 \\
Fourth & 14 & 12.33 \\
\hline Total & 50 & 50.00 \\
\hline
\end{tabular}

$\chi^{2}=2 \cdot 79$ with 3 degrees of freedom; $0.25<\mathrm{p}<0.50$

Associated Anomalies. Thirty-one (62\%) index cases had single or multiple associated anomalies (Table V). This is much greater than the expected evidence of anomalies in the general population. Excluding the complications of chordee and meatal stenosis; which were present in most cases of hypospadias in various degrees, the most frequent association was genito-urinary anomalies (35\%) followed by hernias (15\%). This agrees with the study of Ross et al (1959) where undescended testes $(62 \%)$ were most often encountered followed by hernias ( $32 \%)$.

Consanguinity of Parents. There was no instance of parental consanguinity in our 50 index cases. 
Twins. Four index cases $(4,6,11$, and 42$)$ had unaffected dizygotic twin brothers and one (5) an unaffected twin sister. Identical coronal hypospadias has been reported by Bourne (1961) in 12year-old identical twin brothers.

TABLE V

ASSOCIATED ANOMALIES IN $31(62 \%)$ INDEX CASES

\begin{tabular}{l|c}
\hline \multicolumn{1}{c|}{ Types } & Numbers \\
\hline Genito-Urinary & 18 \\
Cryptorchidism & 9 \\
Bifid scrotum & 5 \\
Others & 4 \\
Hernias & 7 \\
Inguinal & 5 \\
Umbilical & 1 \\
Diaphragmatic & 5 \\
Growth and/or mental retardation & 4 \\
Congenital heart diseases & 4 \\
Gastrointestinal & 3 \\
Central nervous system disorders & 1 \\
Down's syndrome & 32 \\
Miscellaneous & 74 \\
\hline Total & \\
\hline
\end{tabular}

Risk Figures and the Affected Sibs. The best estimate of risk to sibs is perhaps to ascertain affected sibs through index cases. Excluding twins as sibs, the $\mathbf{5 0}$ index cases had a total of $\mathbf{6 2}$ sibs. Of these, $6(9.7 \%)$ were found to have hypospadias, ie with an empirical risk of about 1 in 10 . Sørensen (1953) estimaged it as $9.6 \%$. To calculate the recurrence risk in sibs where the malformation in the index patient was essentially single and not part of multiple malformations, families $1,2,6,7,9,16,18$, $20,25,29,30,31,36,41,45,46$, and 50 were excluded from calculation. This in fact gives a similar recurrence risk of 5 in $48(10.4 \%)$. Though risks for the sons of affected individuals have not been well established, they are probably below these figures. Information on types of hypospadias, presence of associated anomalies, and karyotypes of affected sibs are presented in Table VI. All affected sibs were personally examined at the clinic except in the case of family 23 as the affected sib was not available because he had died of multiple congenital anomalies at four days of age.

TABLE VI

TYPE OF HYPOSPADIAS, ASSOCIATE ANOMALIES, AND KARYOTYPES OF AFFECTED SIBS

\begin{tabular}{|c|c|c|c|}
\hline Family No. & Type of & Associate Anomalies & Karyotype \\
\hline 23 & Unknown & $\begin{array}{l}\text { Multiple congenital } \\
\text { anomalies }\end{array}$ & Not done \\
\hline $\begin{array}{l}24 \\
40 \\
42 \\
49 \\
50\end{array}$ & $\begin{array}{l}\text { Glandar } \\
\text { Glandar } \\
\text { Glandar } \\
\text { Penile } \\
\text { Penile }\end{array}$ & $\begin{array}{l}\text { None } \\
\text { Umbilical hernia } \\
\text { None } \\
\text { None } \\
\text { None }\end{array}$ & $\begin{array}{l}\text { Not done } \\
46, X Y \\
\text { Not done } \\
\text { Not done } \\
46, X Y\end{array}$ \\
\hline
\end{tabular}

In addition to 6 affected with hypospadias among the sibs of propositi, there were two first cousins affected in family 15 . All the affected relatives were surgically confirmed.

Estimation of the Heritability. Since the incidence of hypospadias differs between males and females, the sexes of both propositi and the first degree relatives must be treated separately to yield the estimate of the regression. The incidence of hypospadias in males in the general population is assumed to be estimated without error. The following calculations were according to the method of Falconer (1965). The data needed to estimate the heritability of hypospadias in males are given in Table VII. The 117 male first degree relatives include the 62 brothers, the 4 twin brothers and the 50 normal fathers and one normal son. The regression coefficient for the like sex relative is 0.37 . Heritability of this anomaly is $74.1 \%$ and the standard error of heritability is $12.6 \%$.

\section{TABLE VII}

COMPARISON OF INCIDENCE IN RELATIVES OF INDEX CASES AND IN GENERAL POPULATION

\begin{tabular}{l|c|c|c|c|c|c}
\hline & $\mathrm{A}$ & $\mathrm{N}$ & $\mathrm{q}$ & $\mathrm{p}$ & $\mathrm{x}$ & $\mathrm{a}$ \\
\hline $\begin{array}{l}\text { General population } \\
\text { (males) } \\
\begin{array}{c}\text { Relatives of index } \\
\text { cases (male pro- } \\
\text { positi-male } \\
\text { relatives) }\end{array}\end{array}$ & - & - & 0.0028 & 0.9972 & 2.770 & 3.070 \\
\hline
\end{tabular}

$A=$ observed number of affected individuals in the sample

$\mathbf{N}=$ total number of individuals in the sample.

$\mathbf{q}=$ incidence

$\mathrm{p}=1-\mathrm{q}$

$\mathbf{x}=$ normal deviation of affected individuals, and

$\mathrm{a}=\mathrm{Zq}$ ie, the mean deviation of affected individuals (adopted from Falconer, 1965).

Cytogenetics. Blood cultures were performed on peripheral lymphocytes according to the method of Moorhead et al (1960) with some modifications. For culture of skin tissue, a small piece of skin was obtained from the buttocks and cultured according to the technique of Basrur, Basrur, and Gilman (1963). For autoradiographic studies, tritiated thymidine $(1.9 \mathrm{c} / \mathrm{mM}$ Schwarz Bio Research, $1 \mu \mathrm{C} / \mathrm{ml}$ medium) was added 4 to 5 hours before fixation. Chromosome analysis was performed on 26 index cases. The following three cases were found to have abnormal karyotypes.

CASE 21. Cytogenetic evaluation of 53 metaphase preparations from peripheral blood cultures showed a modal number of 47 with only few cells deviated from this number. Karyotypic analysis of 15 well-spread metaphases revealed the presence of an extra small 
Fig. 1. Metaphase preparation of a peripheral blood cell of case 21 showing chromosome morphology and tritiated thymidine labelling pattern. Note two late replicating Y's and a translocation between long arms of two C group chromosomes probably number 8 and number 12 .

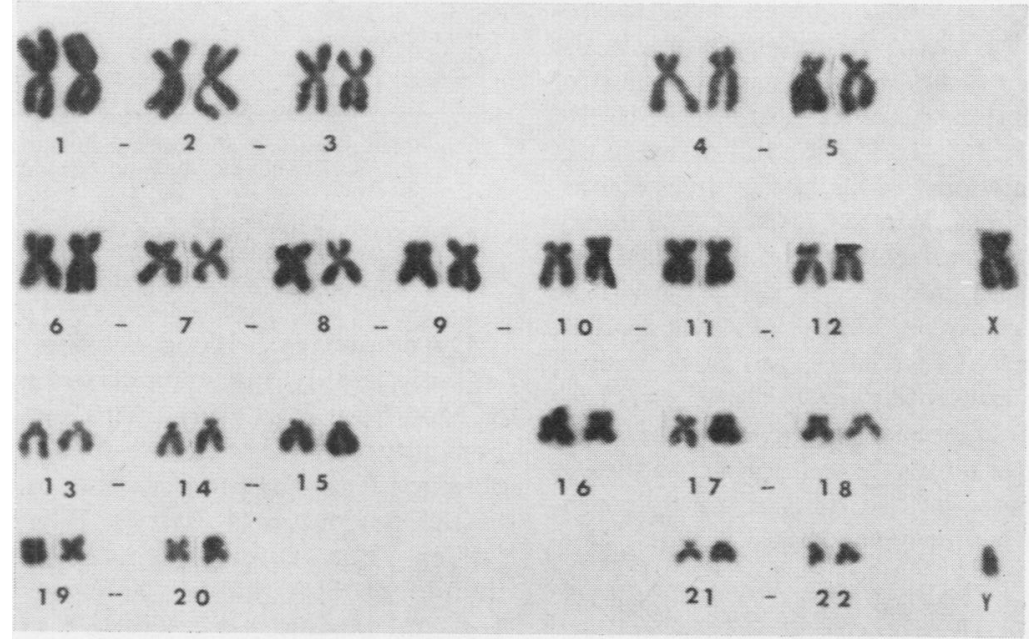

FIG. 2. Karyotype of case 29 from skin culture with 46 chromosomes showing XY sex complement.

acrocentric chromosome, which is interpreted as a $\mathrm{Y}$ sex chromosome by its morphological characteristics and its late replicating pattern from autoradiographic studies, and a translocation involving two chromosomes of the 6-12 group most probably between number 8 and number 12 (Fig. 1). The chromosome analysis of his parents showed no abnormality.
CASE 29. Forty-six chromosomes were present in all of the 20 cells counted from the peripheral blood culture. Detailed karyotypic analysis of 10 metaphases revealed a normal sex chromosome complement. Skin culture, however, showed a two cell-lines, one with $X Y$ and one XX sex complement (Figs. 2 and 3). About $40 \%$ XX cell line in the skin culture probably accounts for the 


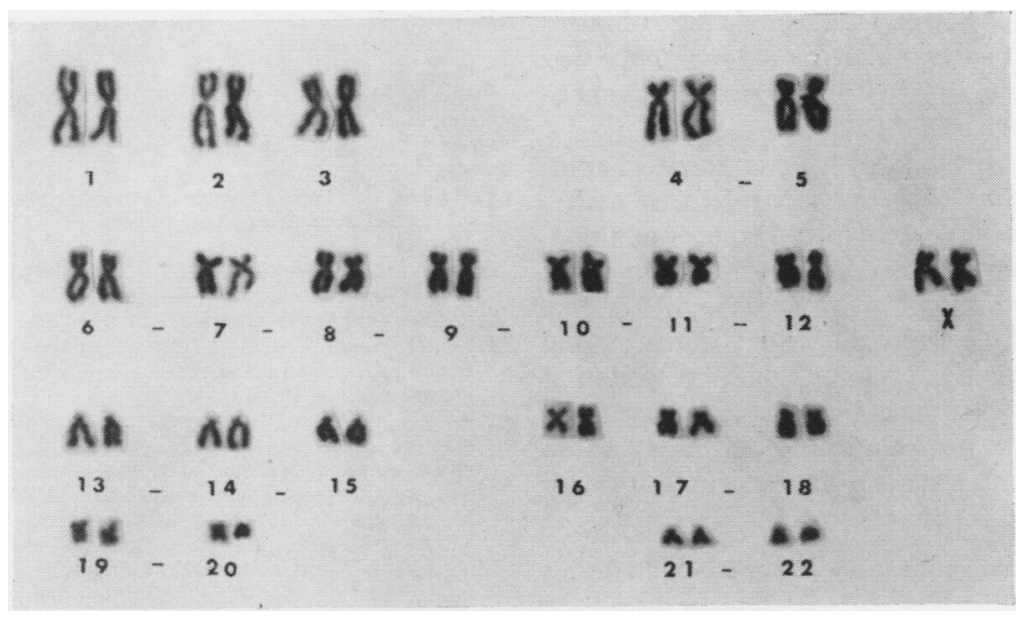

FiG. 3. Karyotype of case 29 from skin culture with 46 chromosomes showing XX sex complement.

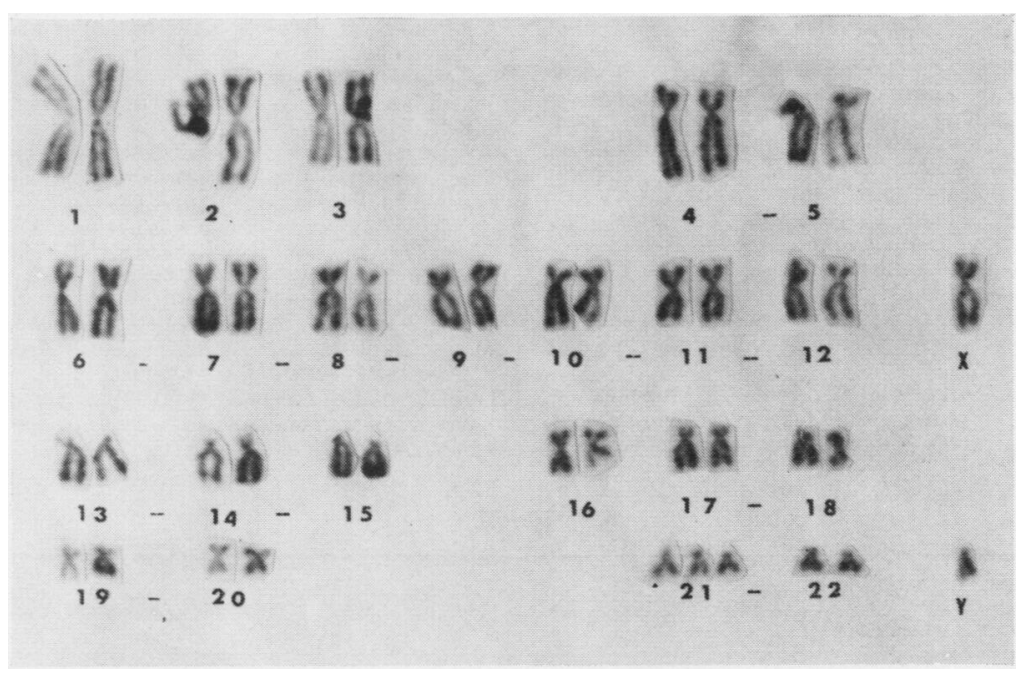

FIG. 4. Karyotype of case 50 from peripheral blood culture with 47 chromosomes showing an extra 21 chromosome.

low buccal smear count ( $9 \%$ chromatin positive, of the patient.

CASE 50. Counts were made of 24 cells from the peripheral blood culture. The modal number was 47 . The karyotypic analysis revealed a chromosome complement of 47,XY,21 + (Fig. 4) which is compatible with his typical clinical features of Down's syndrome.

\section{Summary}

The families of 50 index cases with hypospadias were studied. Of these, $20(40 \%)$ were of glandar type, $23(46 \%)$ of penile type, and $7(14 \%)$ of penoscrotal or perineal type. 
The incidence of hypospadias in relatives of index cases is compared with the estimated incidence in a general population, and the heritability of the anomaly is found to be $74 \cdot 1 \pm 12 \cdot 6 \%$.

Three cases were found to have abnormal karyotypes. Case 21 had XYY sex complement with a translocation involving two chromosomes of the $\mathrm{C}$ group, case 29 had mosaicism for sex chromosome (XX/XY) from skin culture but normal XY sex complement from peripheral blood culture, and case 50 had trisomy 21. Though an increased incidence $(6 \%)$ of chromosomal abnormalities was found in this study, no definite etiologic relationship between certain chromosomal abnormalities and hypospadias could be established.

We are indebted to Professor William J. Schull for his helpful comments.

\section{REFERENCES}

Balodimos, M. C., Lisco, H., Irwin, I., Merill, W., and Dingman, J. F. (1966). XYY karyotype in a case of familial hypogonadism. fournal of Clinical Endocrinology and Metabolism, 26, 443-452.

Basrur, P. K., Basrur, V. R., and Gilman, J. P. W. (1963). A simple method for short term cultures from small biopsies. Experimental Cell Research, 30, 229-232.

Bourne, N. W. (1961). Urologist's Correspondence Club Letter, May 20, Cited from Campbell, M. F. (1963). Urology, Vol. 2, 2nd ed., W. B. Saunders, Philadelphia.

Chen, Y. C., Smith, A., Luthardt, F., Nunes-Vas, C., and Woolley, P. V. (1968). Abnormal chromosome constitutions of various congenital syndromes during 1961-1966. Mammalian Chromosome Newsletter, 9, 7-15.

Chung, C. S. and Myrianthopoulos, N. C. (1968). Racial and prenatal factors in major congenital malformations. American fournal of Human Genetics, 20, 44-60.

Grouchy, J. de, Josso, N., Lamy, M., Frezal, J., Nezelof, C., Feintuch, G. (1963). Syndrome de Klinefelter chez un nourrison hypospade. Caryotype á 46 chromosome. Annales de Pédiatrie, 10, 173-177.
Falconer, D. S. (1965). The inheritance of liability to certain diseases, estimated from the incidence among relatives. Annals of Human Genetics, 29, 51-76.

Fishbein, M. (1963). Birth Defects, Lippincott, Philadelphia. Gates, R. R. (1946). Human Genetics, Macmillan, New York.

Gray, J. (1961). Hypospadias with 47/XXY karyotype. Lancet, 1, 722.

Halbrecht, I. (1960). Nuclear sex determination in azoospermic adults and in newborns with hypospadias. Fertility and Sterility, 11, 112-117.

Hirschhorn, K., Cooper, H. L., and Firschein, I. L. (1965). Deletion of short arms of chromosome 4-5 in a child with defects of midline fusion. Humangenetik, 1, 479-482.

Klotz, H. P. and Sors, C. (1958). A propos du syndrome de Klinefelter et de son diagnostic précoce prépubertaire. Annales d'endocrinologie, 19, 128-133.

Leao, J. C., Neu, R., and Gardner, L. I. (1966). Hypospadias and other anomalies associated with partial deletion of short arms of chromosome No. 4. Lancet, 1, 493-494.

Milcu, S.-M., Negoescu, I., Maximilian, C., Garoiu, M., Augustin, M., and Iliescu, I. (1964). Baiat cu hipospadias si cariotip XYY. Studii si cercetări de endocrinologie, 15, 347-349.

Moorhead, P. S., Nowell, P. C., Mellman, W. J., Battips, D. M., and Hungerford, D. A. (1960). Chromosome preparations of leukocytes cultured from human peripheral blood. Experiment Cell Research, 20, 613-616.

Muldal, S. and Ockey, C. H. (1962). Deletions of Y chromosome in a family with muscular dystrophy and hypospadias. British Medical fournal, 1. 291-294.

Norman, A. P. (1963). Congenital Anomalies in Infancy, Ch. 6, Davis, Philadelphia.

Passarge, E. and Thomson, J. N. (1964). Autoradiography in a boy with XXY karyotype. American fournal of Diseases of Children, 108, 184-188.

Rodriguez, O. T. (1965). Incidencia familiar de ciertas anomalies congenitas urinarias. Revista venezolana de urologia, 17, 321.

Ross, J. F., Farmer, A. W., and Lindsay, W. K. (1959). Hypospadias: A review of 230 cases. Plastic and Reconstructive Surgery and The Transplantation Bulletin, 24, 357-368.

Sørensen, R. (1953). Hypospadias with Special Reference to Etiology. Munksgaard, Copenhagen.

Sorsby, A. (1953). Clinical Genetics. Butterworth, London.

Steiner, F. (1936). Zur Erblichkeit der Hypospadia. Münchener medizinische Wochenschrift, 83, 1271.

Turpin, R. and Lejeune, J. (1960). Le maladies humaines par aberrations chromosomiques. Revue français d'études cliniques et biologiques, 5, 341-347.

\section{APPENDIX I}

\begin{tabular}{|c|c|c|c|c|c|c|c|}
\hline \multirow{2}{*}{$\begin{array}{l}\text { I.D. } \\
\text { No. }\end{array}$} & \multirow{2}{*}{$\begin{array}{l}\text { Birth } \\
\text { Weight } \\
(\mathbf{k g})\end{array}$} & \multirow{2}{*}{$\begin{array}{l}\text { Birth } \\
\text { Order }\end{array}$} & \multicolumn{2}{|c|}{ Age at Birth } & \multirow{2}{*}{ Karyotype* } & \multirow{2}{*}{$\begin{array}{l}\text { Type of } \\
\text { Hypospadias }\end{array}$} & \multirow{2}{*}{ Associated Anomalies } \\
\hline & & & Father & Mother & & & \\
\hline 1 & $4 \cdot 2$ & 2 & 23 & 21 & $46, X Y$ & Glandar & $\begin{array}{l}\text { Hypertelorism, cryptorchidism, hare lip and cleft } \\
\text { palate, mental retardation, aplastic kidney, fron- } \\
\text { tal and facial bone deformity }\end{array}$ \\
\hline 2 & $1 \cdot 9$ & 2 & 23 & 21 & $46, X Y$ & Penile & $\begin{array}{l}\text { Micrognathia, low set ears, prominent occiput, } \\
\text { inguinal hernia, pulmonary hypertension }\end{array}$ \\
\hline $\begin{array}{l}3 \\
4 \\
5 \\
6\end{array}$ & $\begin{array}{l}3 \cdot 4 \\
2 \cdot 3 \\
1 \cdot 5 \\
1 \cdot 9\end{array}$ & $\begin{array}{l}3 \\
1 \\
1 \\
7\end{array}$ & $\begin{array}{l}24 \\
25 \\
24 \\
37\end{array}$ & $\begin{array}{l}25 \\
24 \\
25 \\
29\end{array}$ & $\begin{array}{l}\text { Not done } \\
\text { Not done } \\
\text { Not done } \\
46, X Y\end{array}$ & $\begin{array}{l}\text { Glandar } \\
\text { Glandar } \\
\text { Penile } \\
\text { Penile }\end{array}$ & $\begin{array}{l}\text { None } \\
\text { None } \\
\text { None } \\
\text { Low set ears, micrognathia, high arched palate, }\end{array}$ \\
\hline 7 & $3 \cdot 2$ & 1 & 23 & 21 & $46, X Y$ & Penoscrotal & Bifid scrotum, anomalous development of sacrum \\
\hline $\begin{array}{l}8 \\
9\end{array}$ & $\begin{array}{l}2 \cdot 3 \\
2 \cdot 6\end{array}$ & $\begin{array}{l}1 \\
1\end{array}$ & $\begin{array}{l}28 \\
21\end{array}$ & $\begin{array}{l}24 \\
29\end{array}$ & $\begin{array}{l}46, \mathbf{X Y} \\
46, \mathbf{X Y}\end{array}$ & $\begin{array}{l}\text { Penile } \\
\text { Penile }\end{array}$ & $\begin{array}{l}\text { Cryptorchidism, bronchial asthma, anaemia } \\
\text { Cryptorchidism, growth and mental retardation, }\end{array}$ \\
\hline $\begin{array}{l}10 \\
11 \\
12 \\
13 \\
14 \\
15 \\
16 \\
17 \\
18 \\
19\end{array}$ & $\begin{array}{l}3 \cdot 4 \\
1 \cdot 4 \\
3 \cdot 4 \\
4 \cdot 2 \\
3 \cdot 2 \\
3 \cdot 1 \\
2 \cdot 7 \\
2 \cdot 9 \\
2 \cdot 9 \\
3 \cdot 4\end{array}$ & $\begin{array}{l}3 \\
2 \\
2 \\
1 \\
2 \\
1 \\
3 \\
6 \\
1 \\
4\end{array}$ & $\begin{array}{l}42 \\
41 \\
30 \\
24 \\
28 \\
21 \\
20 \\
32 \\
26 \\
28\end{array}$ & $\begin{array}{l}42 \\
34 \\
29 \\
22 \\
30 \\
16 \\
20 \\
25 \\
25 \\
28\end{array}$ & $\begin{array}{l}\text { Not done } \\
46, X Y \\
\text { Not done } \\
\text { Not done } \\
\text { Not done } \\
46, X Y \\
46, X Y \\
\text { Not done } \\
\text { Not done } \\
46, X Y\end{array}$ & $\begin{array}{l}\text { Glandar } \\
\text { Penile } \\
\text { Glandar } \\
\text { Penile } \\
\text { Penile } \\
\text { Penoscrotal } \\
\text { Glandar } \\
\text { Glandar } \\
\text { Penile } \\
\text { Penile }\end{array}$ & $\begin{array}{l}\text { Hydrocephalus, convulsive disorder } \\
\text { None } \\
\text { None } \\
\text { None } \\
\text { None } \\
\text { Bifid scrotum } \\
\text { Micrognathia, growth and mental retardation } \\
\text { Nephrosis } \\
\text { Tetralogy of Fallot, iron-deficiency anaemia } \\
\text { Umbilical hernia }\end{array}$ \\
\hline
\end{tabular}


Appendix I-continued

\begin{tabular}{|c|c|c|c|c|c|c|c|}
\hline \multirow{2}{*}{$\begin{array}{l}\text { I.D. } \\
\text { No. }\end{array}$} & \multirow{2}{*}{$\begin{array}{c}\text { Birth } \\
\text { Weight } \\
(\mathbf{k g})\end{array}$} & \multirow{2}{*}{$\begin{array}{l}\text { Birth } \\
\text { Order }\end{array}$} & \multicolumn{2}{|c|}{ Age ot Birth } & \multirow{2}{*}{ Karyotype* } & \multirow{2}{*}{$\begin{array}{l}\text { Type of } \\
\text { Hypospadias }\end{array}$} & \multirow{2}{*}{ Associated Anomalies } \\
\hline & & & Father & Mother & & & \\
\hline 20 & $3 \cdot 0$ & 1 & 20 & 18 & $46, X Y$ & Penile & Phocomelia, bifid scrotum. imperforated anus, \\
\hline 21 & $1 \cdot 6$ & 2 & 35 & 25 & $\begin{array}{l}\text { 47,XYY, } \\
\text { ?t }(\mathbf{C q}-; \mathrm{Cq}+)\end{array}$ & Penile & $\begin{array}{l}\text { Cryptorchidism, haemangioma of chin, hyper- } \\
\text { bilirubinaemia, growth retardation }\end{array}$ \\
\hline $\begin{array}{l}22 \\
23 \\
24 \\
25\end{array}$ & $\begin{array}{l}2 \cdot 0 \\
1 \cdot 8 \\
3 \cdot 3 \\
3 \cdot 4\end{array}$ & $\begin{array}{l}2 \\
4 \\
2 \\
1\end{array}$ & $\begin{array}{l}31 \\
31 \\
27 \\
24\end{array}$ & $\begin{array}{l}32 \\
32 \\
24 \\
22\end{array}$ & $\begin{array}{l}\text { Not done } \\
46, X Y \\
\text { Not done } \\
46, X Y\end{array}$ & $\begin{array}{l}\text { Penoscrotal } \\
\text { Penoscrotal } \\
\text { Glandar } \\
\text { Penile }\end{array}$ & $\begin{array}{l}\text { Bronchial asthma } \\
\text { None } \\
\text { None } \\
\text { Dextrocardia, atrial septal defect, diagrammatic }\end{array}$ \\
\hline $\begin{array}{l}26 \\
27 \\
28 \\
29\end{array}$ & $\begin{array}{l}3 \cdot 1 \\
5 \cdot 2 \\
0 \cdot 9 \\
3 \cdot 8\end{array}$ & $\begin{array}{l}3 \\
3 \\
1 \\
1\end{array}$ & $\begin{array}{l}35 \\
37 \\
25 \\
20\end{array}$ & $\begin{array}{l}29 \\
36 \\
22 \\
19\end{array}$ & $\begin{array}{l}\text { Not done } \\
\text { Not done } \\
46, X Y \\
46, X Y \\
\text { (Blood) } \\
46, X X / 46, X Y \\
\text { (Skin) }\end{array}$ & $\begin{array}{l}\text { Penile } \\
\text { Glandar } \\
\text { Penile } \\
\text { Penile }\end{array}$ & $\begin{array}{l}\text { None } \\
\text { Convulsive disorder } \\
\text { Cryptorchidism, high arched palate } \\
\text { Cryptorchidism, imperforated anus, omphalocele }\end{array}$ \\
\hline $\begin{array}{l}30 \\
31\end{array}$ & $\begin{array}{l}5 \cdot 0 \\
1 \cdot 7\end{array}$ & $\begin{array}{l}1 \\
1\end{array}$ & $\begin{array}{l}19 \\
20\end{array}$ & $\begin{array}{l}17 \\
20\end{array}$ & $\begin{array}{l}46, X Y \\
46, X Y\end{array}$ & $\begin{array}{l}\text { Penile } \\
\text { Penile }\end{array}$ & $\begin{array}{l}\text { Polydactyly, hydrocephalus, microphthalmia } \\
\text { Cryptorchidism, inguinal hernia, growth retarda- } \\
\text { tion, intestinal obstruction }\end{array}$ \\
\hline $\begin{array}{l}32 \\
33 \\
34 \\
35 \\
36\end{array}$ & $\begin{array}{l}4 \cdot 0 \\
3 \cdot 6 \\
2 \cdot 3 \\
1 \cdot 9 \\
2 \cdot 5\end{array}$ & $\begin{array}{l}3 \\
2 \\
7 \\
1 \\
1\end{array}$ & $\begin{array}{l}24 \\
27 \\
30 \\
22 \\
29\end{array}$ & $\begin{array}{l}20 \\
22 \\
29 \\
17 \\
27\end{array}$ & $\begin{array}{l}\text { Not done } \\
46, X Y \\
\text { Not done } \\
\text { Not done } \\
46, X Y\end{array}$ & $\begin{array}{l}\text { Glandar } \\
\text { Penile } \\
\text { Glandar } \\
\text { Glandar } \\
\text { Penile }\end{array}$ & $\begin{array}{l}\text { None } \\
\text { None } \\
\text { None } \\
\text { None } \\
\text { Hypertelorism, low set ears, inguinal hernia, }\end{array}$ \\
\hline 37 & $3 \cdot 1$ & 1 & 22 & 20 & $46, X Y$ & Glandar & $\begin{array}{l}\text { Pyloric stenosis, bifid scrotum, inguinal hernia, } \\
\text { hydrocele }\end{array}$ \\
\hline $\begin{array}{l}38 \\
39 \\
40 \\
41 \\
42 \\
43 \\
44 \\
45 \\
46\end{array}$ & $\begin{array}{l}3 \cdot 3 \\
1 \cdot 6 \\
3 \cdot 1 \\
3 \cdot 4 \\
2 \cdot 4 \\
2 \cdot 9 \\
3 \cdot 2 \\
1 \cdot 8 \\
3 \cdot 1\end{array}$ & $\begin{array}{l}1 \\
1 \\
3 \\
1 \\
1 \\
5 \\
1 \\
1 \\
1 \\
1\end{array}$ & $\begin{array}{l}20 \\
20 \\
32 \\
22 \\
34 \\
26 \\
23 \\
22 \\
25\end{array}$ & $\begin{array}{l}21 \\
19 \\
29 \\
22 \\
31 \\
22 \\
18 \\
19 \\
25\end{array}$ & $\begin{array}{l}\text { Not done } \\
\text { Not done } \\
46, X Y \\
\text { Not done } \\
\text { Not done } \\
\text { Not done } \\
46, X Y \\
\text { Not done } \\
\text { Not done }\end{array}$ & $\begin{array}{l}\text { Glandar } \\
\text { Glandar } \\
\text { Glandar } \\
\text { Penoscrotal } \\
\text { Glandar } \\
\text { Glandar } \\
\text { Penoscrotal } \\
\text { Glandar } \\
\text { Penile }\end{array}$ & $\begin{array}{l}\text { None } \\
\text { Cryptorchidism } \\
\text { Cryptorchidism, bifid scrotum } \\
\text { Tracheo-oesophageal fistula } \\
\text { None } \\
\text { Hydrocele } \\
\text { None } \\
\text { Tetralogy of Fallot, cleft palate } \\
\text { Ventricular septal defect, coloboma, inguinal }\end{array}$ \\
\hline 47 & 2.9 & 1 & 31 & 25 & $46, X Y$ & Penile & Talipes equinovarum, speech delay, malformed \\
\hline $\begin{array}{l}48 \\
49 \\
50\end{array}$ & $\begin{array}{l}3 \cdot 3 \\
1 \cdot 8 \\
3 \cdot 1\end{array}$ & $\begin{array}{l}1 \\
1 \\
5\end{array}$ & $\begin{array}{l}26 \\
31 \\
31\end{array}$ & $\begin{array}{l}24 \\
22 \\
33\end{array}$ & $\begin{array}{l}\text { Not done } \\
46, X Y \\
47, X Y, 21+\end{array}$ & $\begin{array}{l}\text { Glandar } \\
\text { Penoscrotal } \\
\text { Penile }\end{array}$ & $\begin{array}{l}\text { None } \\
\text { None } \\
\text { Down's syndrome }\end{array}$ \\
\hline
\end{tabular}

* Karyotype being expressed according to Chicago Conference (1966).

APPENDIX II

SIBSHIPS ARRANGED IN THE ORDER OF BIRTH IN 50 FAMILIES

\begin{tabular}{|c|c|c|c|}
\hline Families & Sipships & Families & Sibships \\
\hline $\begin{array}{l}1 \\
2 \\
3\end{array}$ & $\begin{array}{l}\text { NH } \\
\text { NH } \\
\text { NNH } \star N\end{array}$ & $\begin{array}{l}26 \\
27 \\
28\end{array}$ & $\begin{array}{l}\text { NNH } \\
\text { NNH } \\
\text { H^ }\end{array}$ \\
\hline 4 & $\mathrm{H}^{\star} \mathrm{N}$ & 29 & $\mathbf{H} \star$ \\
\hline 5 & $\widehat{\mathrm{H}^{\star} \mathrm{N}}$ & 30 & $\mathrm{H} \star$ \\
\hline $\begin{array}{r}6 \\
7 \\
8 \\
9 \\
10\end{array}$ & 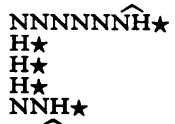 & $\begin{array}{l}31 \\
32 \\
33 \\
34 \\
35\end{array}$ & 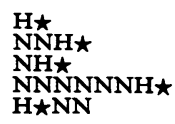 \\
\hline $\begin{array}{l}11 \\
12 \\
13 \\
14 \\
15 \\
16\end{array}$ & 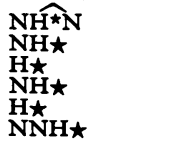 & $\begin{array}{l}36 \\
37 \\
38 \\
39 \\
40 \\
41\end{array}$ & $\begin{array}{l}\mathrm{H} \\
\mathrm{H} \\
\mathrm{H} \\
\mathrm{H} \\
\mathrm{H} \\
\mathrm{NHH} \\
\mathrm{H}\end{array}$ \\
\hline $\begin{array}{l}17 \\
18 \\
19 \\
20 \\
21 \\
22 \\
23 \\
24 \\
25\end{array}$ & 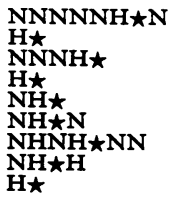 & $\begin{array}{l}42 \\
43 \\
44 \\
45 \\
46 \\
47 \\
48 \\
49 \\
50\end{array}$ & $\begin{array}{l}\text { NHNNH } \\
H \star \\
H \star \\
H \star \\
H \star \\
H \star \\
H \star \\
H \star \\
H \star H \\
N N N H H \star N\end{array}$ \\
\hline
\end{tabular}

$\mathrm{N}=$ Normal $; \mathrm{H}=$ hypospadiac; $\star=$ index patient; $\hat{\Lambda}=$ fraternal twins. 